\title{
Fast Dynamic Surfactant Reduces Aggregation of Biologics
}

Joshua Katz

March 23, 2020

ACS National Meeting, Philadelphia, PA 


\section{A note to the reader}

These slides were originally intended to be presented at the 2020 ACS Spring National Meeting in Philadelphia, PA. Due to that meeting's cancellation, I am now sharing the slides through

SciMeetings. Unpublished data has been removed, and I hope to be able to share that data in another forum soon.

If you have any questions about this presentation or DuPont's work in developing FM1000 for the biopharmaceutical industry, please do not hesitate to reach out to me.

Best regards, Josh

Joshua.katz@dupont.com 


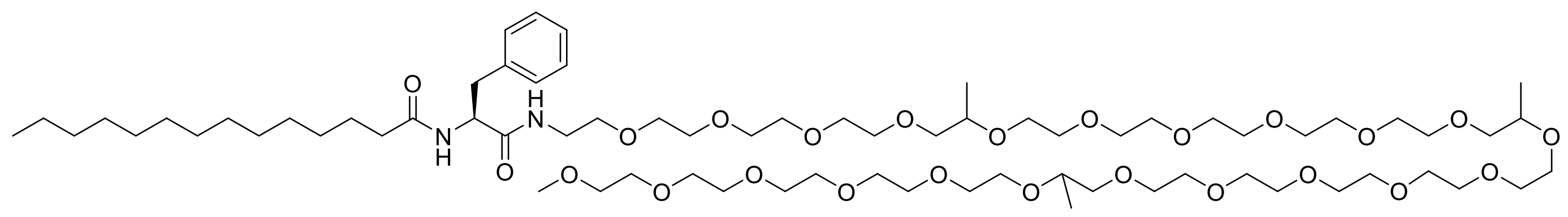

Derived from commonly used biomaterials with wellestablished safety profiles

Amide bonds utilized to resist hydrolysis

Vast library of structures feasible through straightforward synthesis schemes 


\section{Surfactant Properties}

\begin{tabular}{|c|c|c|c|c|}
\hline Property & PS80 & PS20 & P0188 & FM1000 \\
\hline $\begin{array}{c}\text { Bond } \\
\text { Structure }\end{array}$ & Ester bond & Ester bond & All ether & Amide bond \\
\hline $\begin{array}{l}\text { Chemical } \\
\text { Shape }\end{array}$ & Branched & Branched & Linear & Linear \\
\hline $\begin{array}{c}\text { Average MW } \\
(\mathrm{Da})^{\mathrm{a}}\end{array}$ & 1300 & 1200 & 8300 & 1400 \\
\hline Polydispersity & $\begin{array}{l}\text { Mixture of } \\
\text { species }\end{array}$ & $\begin{array}{l}\text { Mixture of } \\
\text { species }\end{array}$ & Narrow & Narrow \\
\hline HLB $^{b}$ & 15 & 16.7 & 17 & 12 \\
\hline CMC (ppm)c & 5.5 & 6.2 & 6.0 & 0.55 \\
\hline $\begin{array}{c}\mathrm{Y}(0.1 \mathrm{mg} / \mathrm{mL}) \\
(\mathrm{mN} / \mathrm{m})\end{array}$ & 45 & 36 & 50 & 41 \\
\hline
\end{tabular}

a. Based on the major species. b. Calculated using the equation HLB $=20^{*} f_{H}$ where $f_{H}$ is the mass fraction of the molecule that is hydrophilic. c. Calculated by intersection of lines of best fit to surface tension vs concentration curves. 


\section{FM1000 at $0.05 \mathrm{mg} / \mathrm{mL}$ drops to equilibrium $>10 \mathrm{x}$ faster both with and without IgG compared to PS20 at $0.1 \mathrm{mg} / \mathrm{mL}$.}

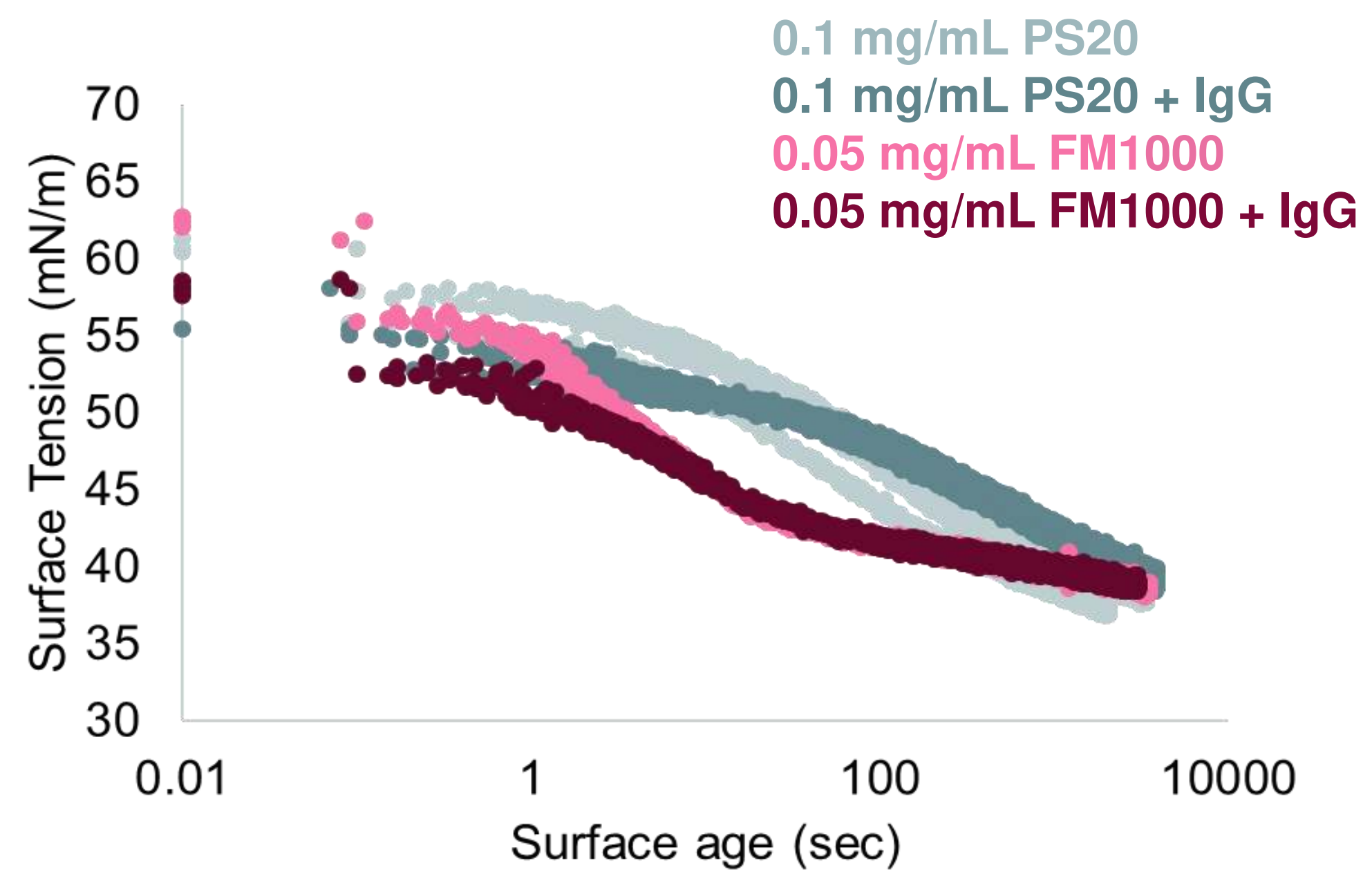




\section{FM1000 stabilizes IgG at appreciable lower concentration or for longer times}

Concentration required to keep aggregates to certain arbitrary size under fixed stress

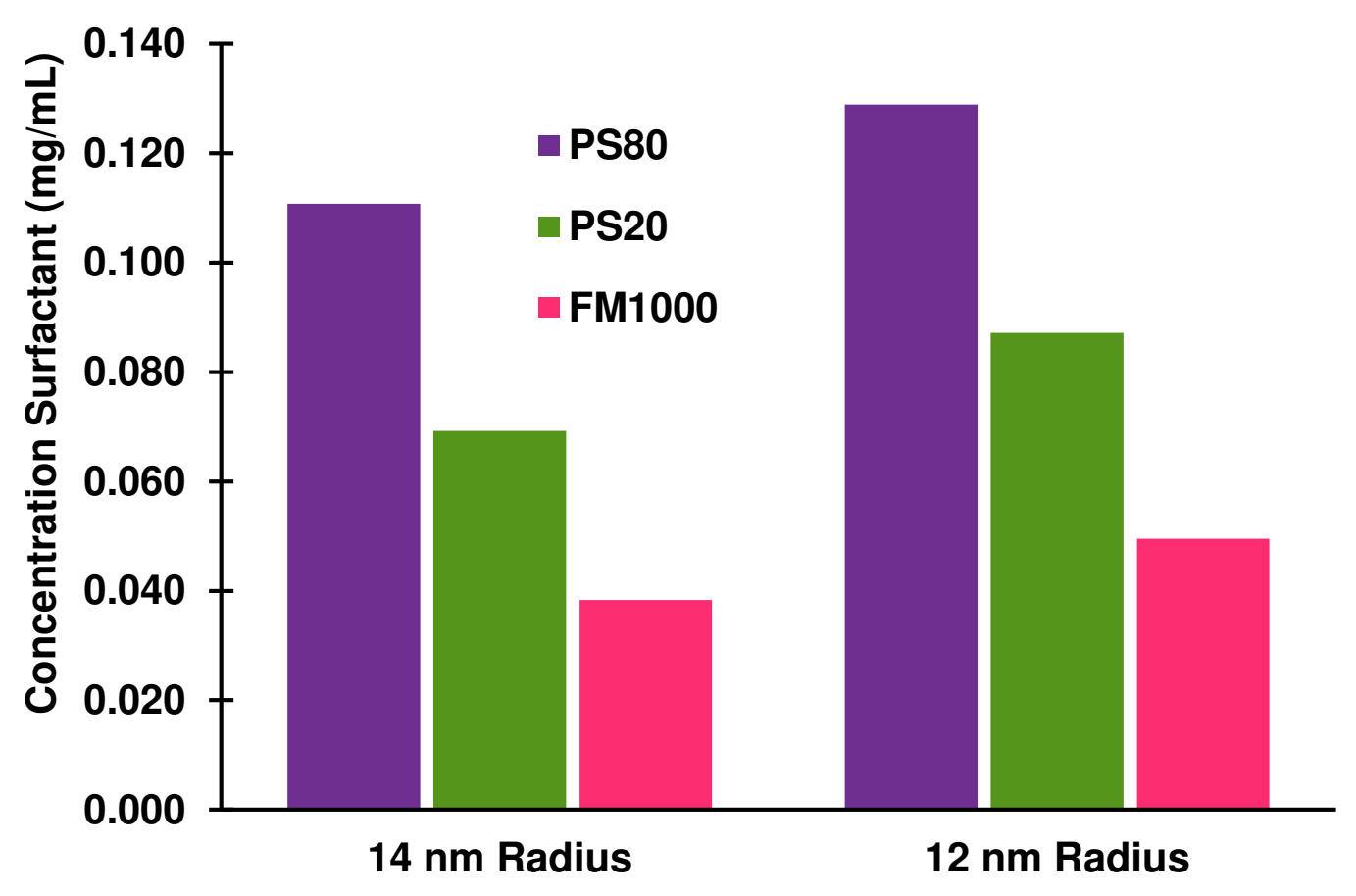

Time to aggregate with fixed surfactant concentration

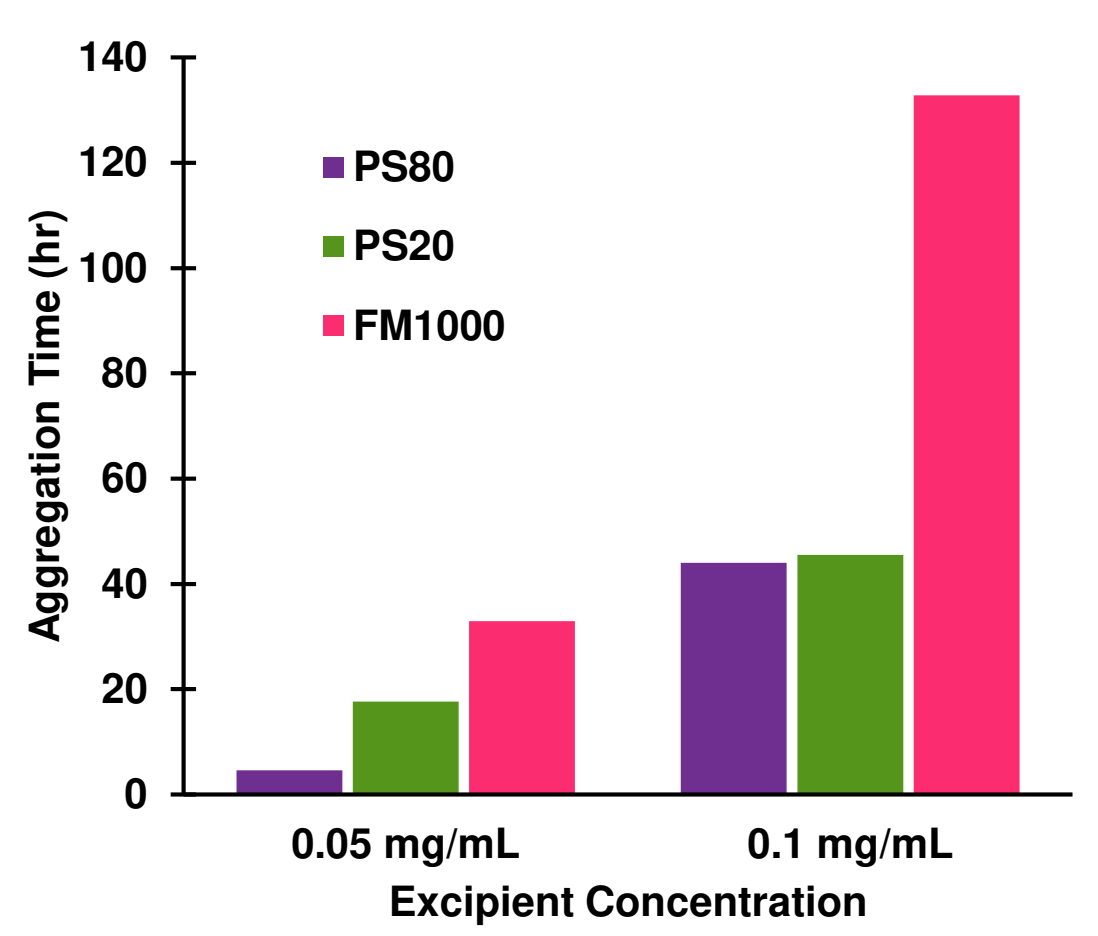




\section{FM1000 mitigates agitation stress for Orencia}

Orencia reformulated to $5 \mathrm{mg} / \mathrm{mL}$ abatacept and $0.1 \mathrm{mg} / \mathrm{mL}$ surfactant, $\mathrm{pH} 5$ (citrate buffer)

$2 \mathrm{~mL}$ added to and sealed into $5 \mathrm{~mL}$ vials

Vials shaken on their side at $150 \mathrm{rpm}$

Aliquots analyzed by SEC:

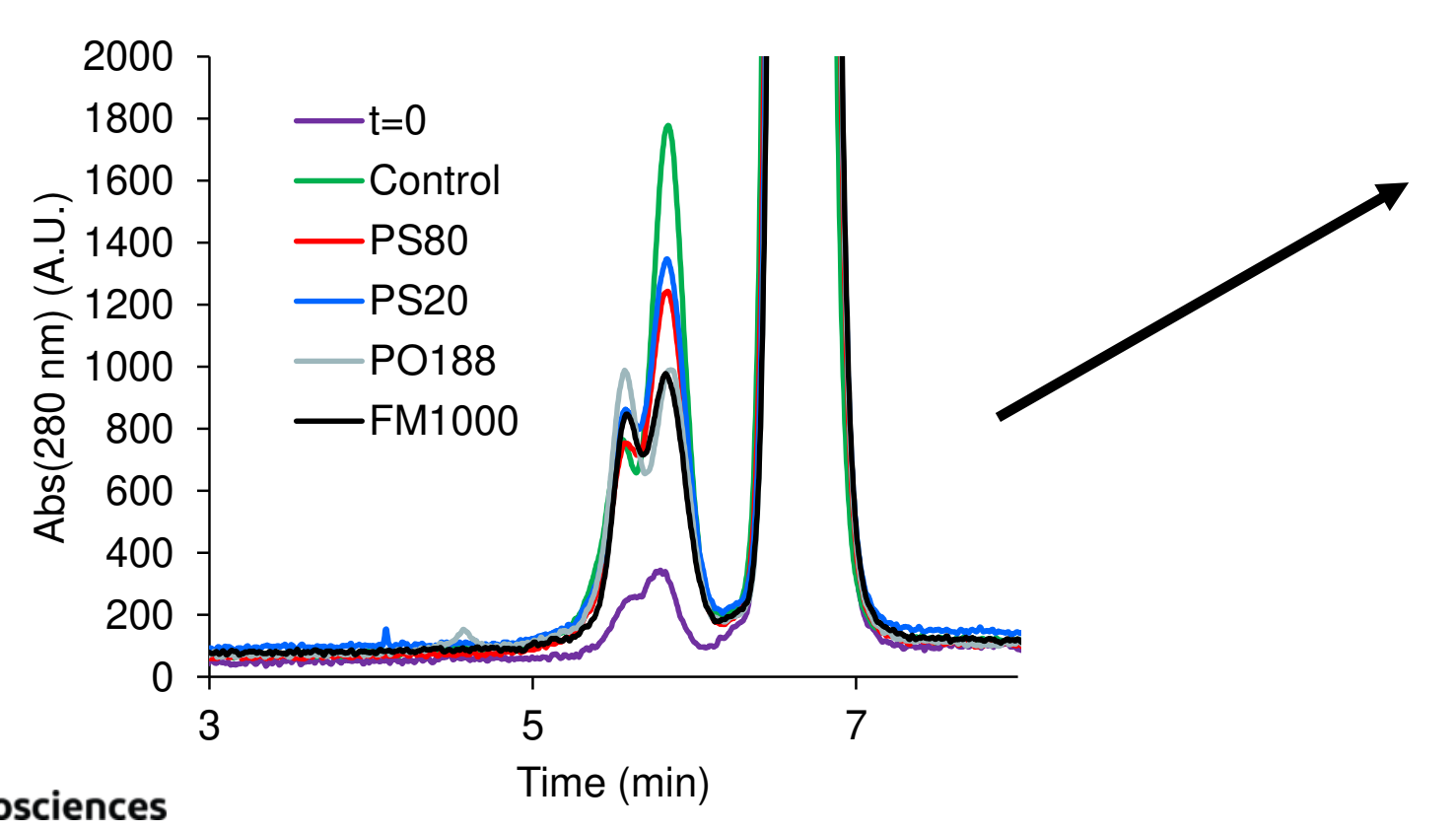

Percent monomer remaining

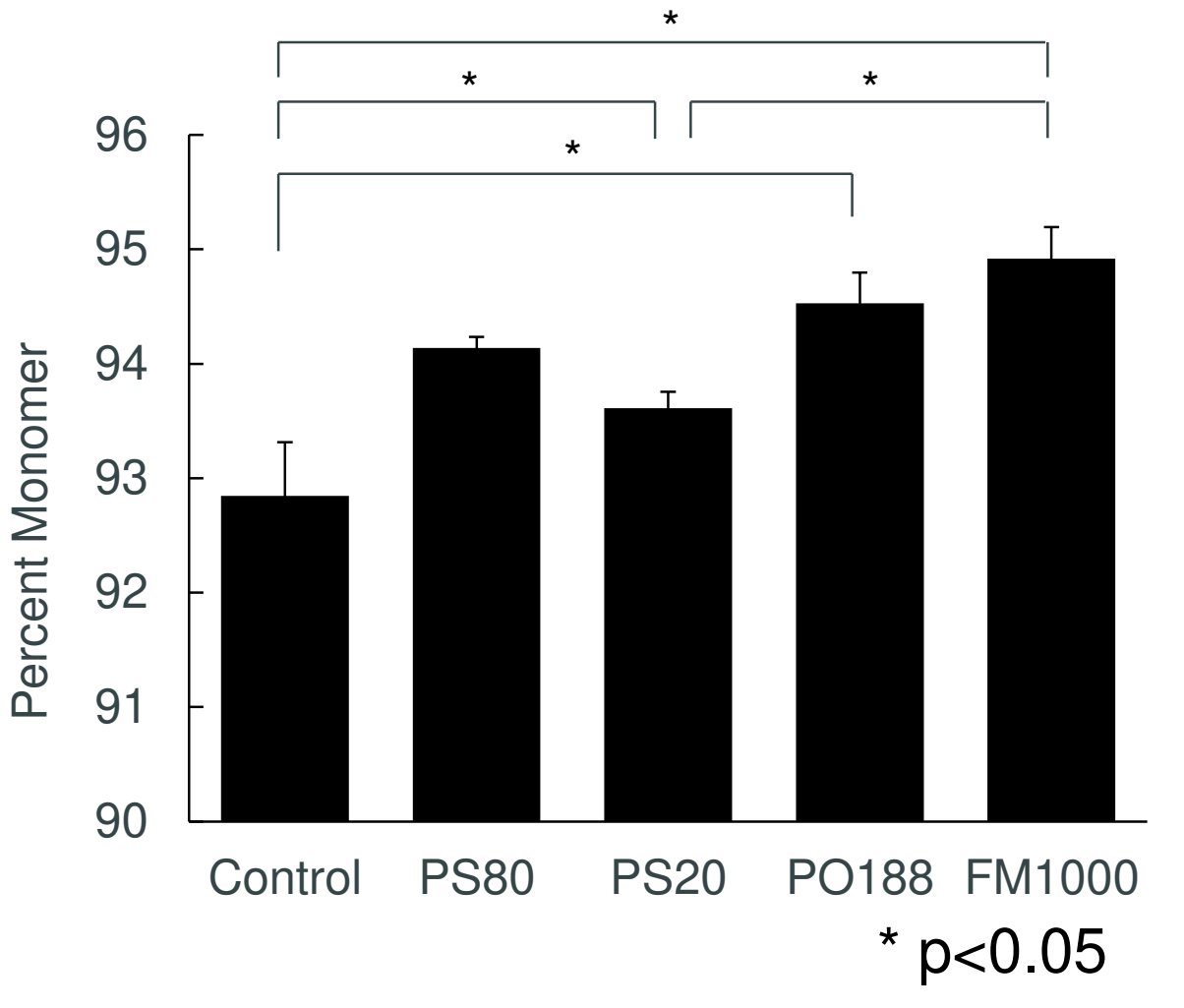




\section{FM1000 mitigates agitation stress of Orencia in dilute conditions IV Bags}

$4 \mathrm{~mL}$ formulations of $10 \mathrm{mg} / \mathrm{mL}$ abatacept and $2.5 \mathrm{mg} / \mathrm{mL}$ surfactant injected into $250 \mathrm{~mL}$ IV bags (Baxter) containing $196 \mathrm{~mL}$ 0.9\% saline

Bags shaken on a rotary shaker at $125 \mathrm{rpm}$ for $24 \mathrm{hrs}$ with samples analyzed by SEC

SEC traces following agitation

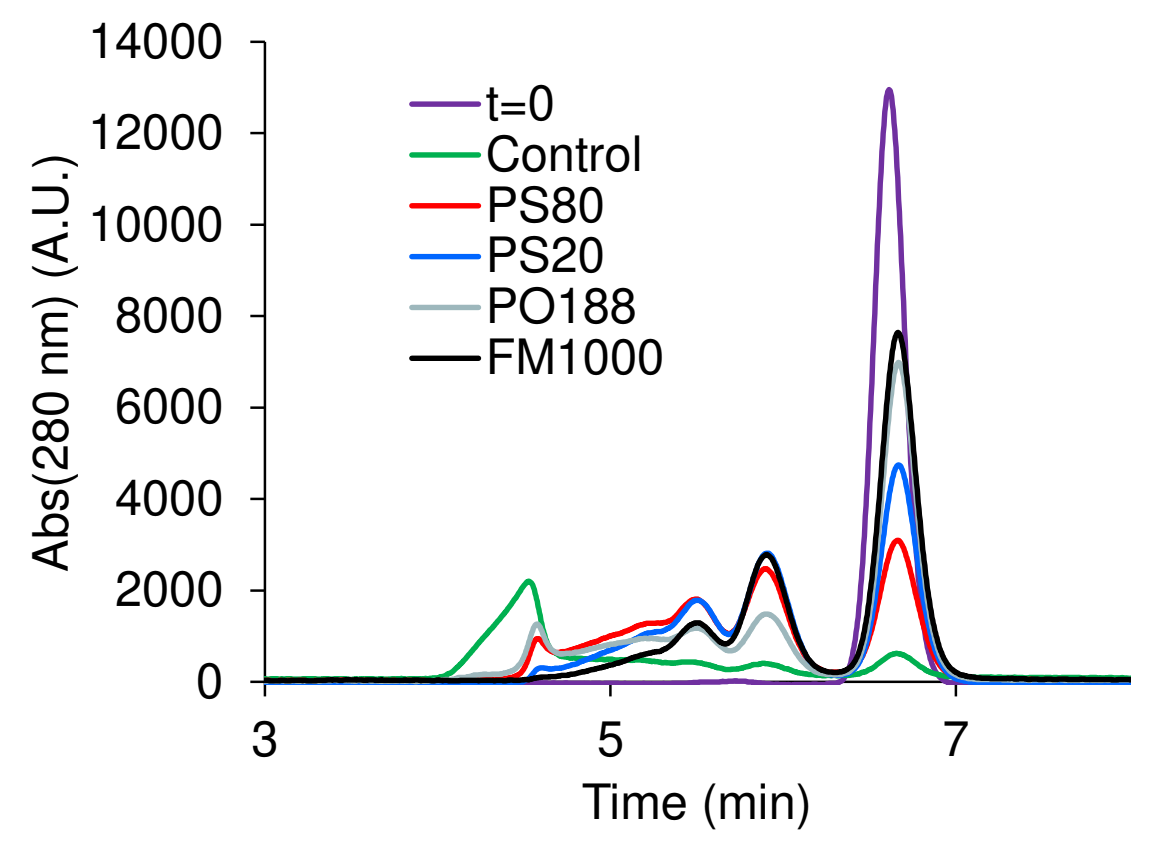

Distribution of aggregates at $24 \mathrm{hrs}$

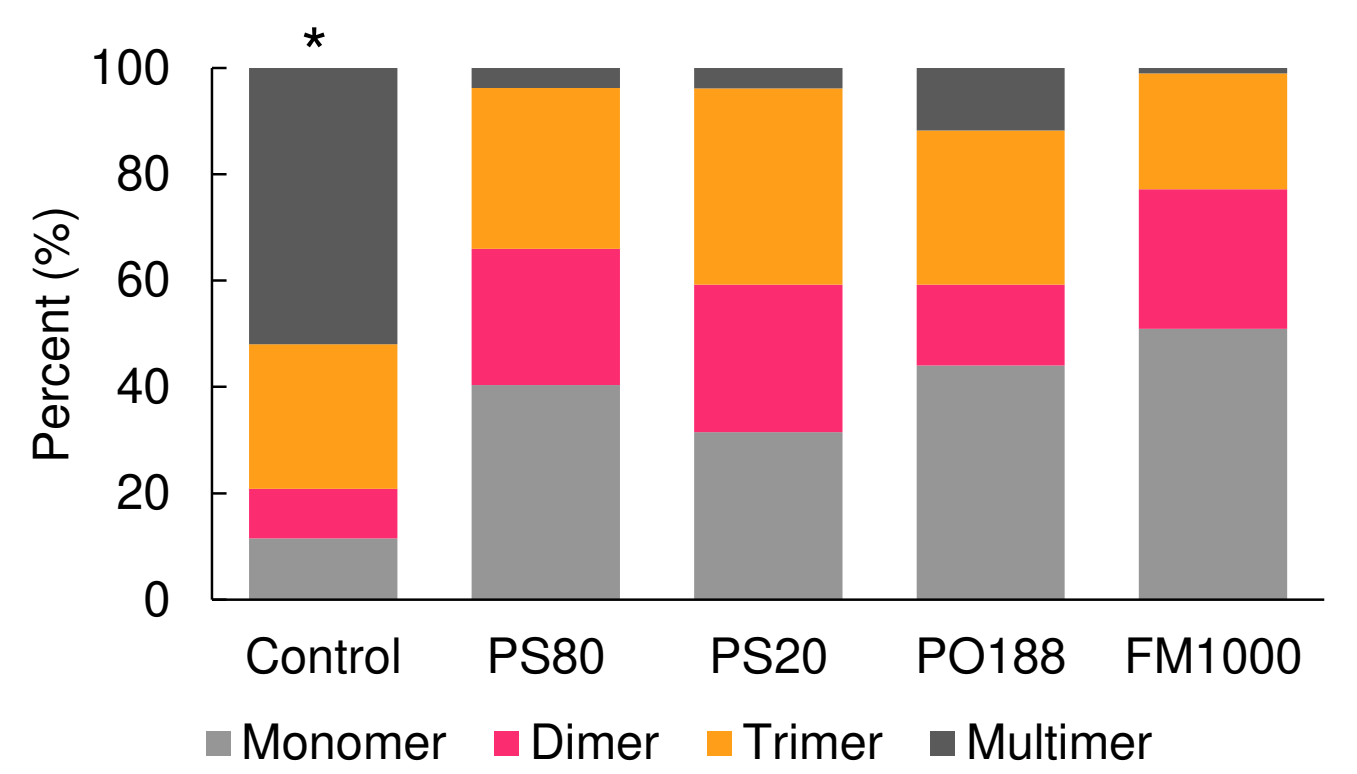

* Control sample had lost $~ 50 \%$ of its total protein content at 24 hrs. All other samples were within $5 \%$ of initial protein content 


\section{FM1000 Mitigates Agitation Stresses for Cetuximab (Erbitux) at Very Low Level Surfactant}
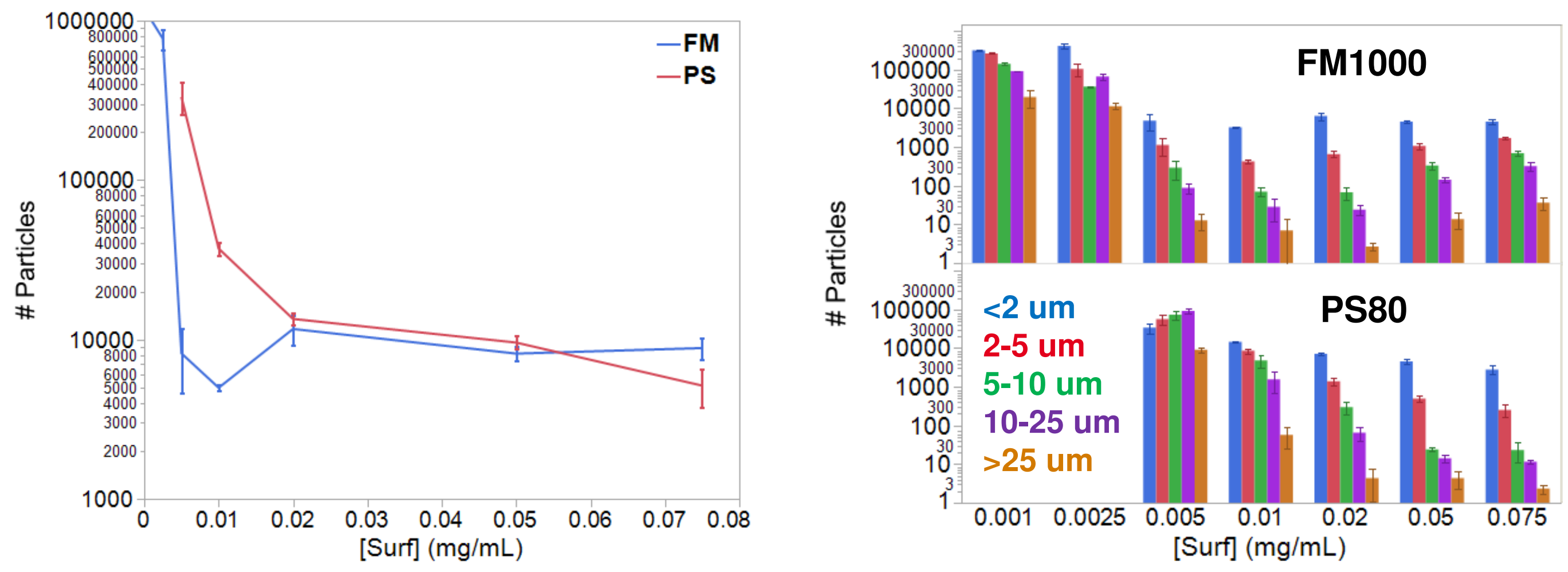


\section{Summary}

- New surfactant, FM1000, is cleaner and more stable than incumbent technologies.

- FM1000 is more dynamic and reduces surface tension significantly faster than PS80, PS20 or PO188.

- Formulations with various protein drug models demonstrate 2-3x improvement in protein stability performance compared to next best technology when exposed to agitation stresses.

- Ongoing work focused on process development, toxicology, and continuing to understand surface and protein interactions. 


\section{Acknowledgements}

- DuPont: Susan Jordan, Ben Yezer, Abi Nolin, Miriam Putterman, Hannah Ma, Oliver Petermann, Koudi Zhu 


\section{IOUPONT.}

DuPont $^{\mathrm{TM}}$, the DuPont Oval Logo and Danisco® logo are trademarks or registered trademarks of DuPont or its affiliates. Copyright @ 2019 DuPont de Nemours Inc. All rights reserved.

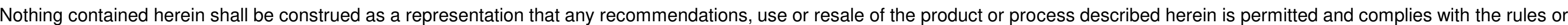
regulations of any countries, regions, localities, etc., or does not infringe upon patents or other intellectual property rights of third parties.

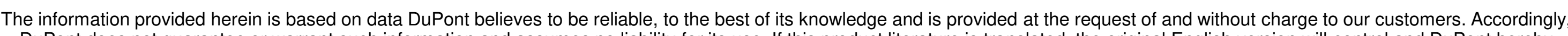

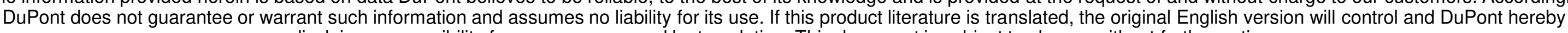
disclaims responsibility for any errors caused by translation. This document is subject to change without further notice. 